\title{
Neurology \& Neurotherapy Open Access Journal
}

\section{Social Support Network and Quality of Life in Multiple Sclerosis Patients}

David C*
Department of Neurology, Centro Hospital de Sao Joao, Portugal

*Corresponding author: David Costa, Department of Neurology, Centro Hospitalar de São João, EPE Prof. Alameda Hernâni Monteiro 4200 Porto - Portugal, Tel: 938447775; E-mail: dcac.costa@gmail.com

\section{Research Article}

Volume 2 Issue 1

Received Date: November 29, 2016

Published Date: January 19, 2017

\section{Abstract}

Aim: To analysis the relationship between social support network (SSN) and health related quality of life (HRQOL) in multiple sclerosis (MS) patients.

Methods: The sample is composed by 150 MS consecutive patients attending our MS Clinic. To assess the sociodemographic data a specifically designed questionnaire was applied. The HRQOL dimensions were measured with ShortForm Health Survey Questionnaire-SF36 and SSN with the Medical Outcomes Study Social Support Survey. The Spearman's correlation was used to compare the magnitude of relationship between SSN and HRQOL.

Results: The mean patient age was 41.7 years $( \pm 10.4$; range: $18-70 \mathrm{yr})$; the mean EDSS was $2.5( \pm 2.4$; range: $0-9)$. Was found a statistically significant correlation between the structure of SSN and HRQOL.

Conclusion: SSN composition, social group membership and participation in voluntary work have an important role in HRQOL of patients with MS.

Keywords: Social support network; Multiple Sclerosis; Health related quality of life

\section{Introduction}

Multiple Sclerosis (MS) is a chronic illness of the central nervous system which affects the physical [1], psychological [2] and social functions [3] of patients. These disturbances have a negative impact in the daily life activities and in the quality of life of patients who are in socially disadvantaged [4] because they often lose their jobs, economic and social status, friends and family [5-7].

In the last two decades, drug therapies which modify the MS natural history $[8,9]$ and the development of physical and psychological rehabilitation techniques [10], represented a major contribution to improve the quality of life of patients and promote their adaptation to the illness [11]. However, as those therapies are not curative and MS is a progressive disease, the importance of social support in the long-term must be highlighted. In this field, several studies have shown that social support is an important positive factor in quality of life related with health (HRQOL) of patients with MS and may decrease their depressive symptoms [3,12-16].

Conceptually, social support is a function of the social network that represents the social relationships with which each person interacts, maintains contact or some form of share [3]. These concepts are frequently described as equivalent, but, in fact, they are different and 


\section{Neurology \& Neurotherapy Open Access Journal}

have a distinct practical expression [17]. In practice, the social network is made up of all people, with whom the contact is maintained, in which concerns the frequency, the social ties, involvement in religious groups, voluntary associations and other groups [18].

The social support network (SSN) is a subset of social network in which people are linked by social roles and relationships, whose functions are the exchange of emotional support, financial assistance, guidance and advice in a variety of situations, particularly, when someone is sick [19]. The SSN may be measured by composition, size and participation in sports groups, social meetings and voluntary work. Sociological studies conducted in Portugal describe that different types of social support is provided by SSN, specifically, by close family members [20]. This evidence reveals that the structure of social support network seems to influence the social support that is provided.

Research about the relationship between SSN and HRQOL show that participation in supporting groups is strongly linked to the decrease of anxiety and to the satisfaction with life [21]. Other studies about HRQOL with chronic patient several that their SSN is less than the SSN of healthy people $[19,22]$. The size of SSN is less important for a patient than the ties among people. For patients with Hodgkin's lymphoma, the composition of the SSN, for example, friends or close family is associated with a better HRQOL [23]. However, there are no studies on the association between SSN of MS patients and HRQOL.

All these aspects are the major reason for the aim of this study that analyzes the relationship between the SSN of patients with MS and their HRQOL.

\section{Patients and Methods}

\section{Patients}

The sample includes 150 adult patients with the diagnosis of MS according to the McDonald criteria [24], consecutively evaluated at the Multiple Sclerosis Outpatient Clinic of Hospital S. Joao, Porto, who gave their informed consent. Illiterate patients were excluded, as well as those with physical and mental disabilities prior to the onset of disease. The Ethics Committee of Hospital S. Joao approved the study.

\section{Methods}

Clinical data about the MS history, such as duration, clinical course and disability assessed by the Expanded
Disability Status Score (EDSS), were collected from medical records.

Demographic data (age, gender, marital status, education level, profession) and the evaluation of the social support network and quality of life were obtained by an interview using a questionnaire specifically designed to this study.

\section{Instruments}

The EDSS score obtained after rating in the different Kurtzke functional systems is the most widely used scale for assessing disability of patients with MS. It is an ordinal scale with a range of values from 0 corresponding to a normal neurological examination and 10 to death due to MS. It shows increments by 0.5 between units except between 0 and 1 . The mild disability was determined by scores from $0-3.5$, moderate disability scores by between $4.0-6.0$ and severe disability by scores greater than or equal to $6.5[25]$.

The Medical Outcomes Study Social Support Survey (MOS-SSS) was used to assess social support network. This scale was created and tested in a study of 2987 adult users of health services in Boston, Chicago and Los Angeles who had at least one of the following chronic diseases: hypertension, diabetes, coronary heart disease or depression [26]. The scale was translated and validated for Portuguese language by Griep et al. [18]. MOS-SSS is composed by two subscales, one to assess social support network and another to assess social support. The social support network subscale has 5 questions about composition, size and social contact frequency.

HRQOL was assessed using the Health Status Questionnaire (SF-36v2) Portuguese version of the Medical Outcome Study 36-Item Health Survey Short Form (SF-36) [27]. It is an evaluation scale to assess HRQOL adapted and validated for the Portuguese population that measures eight dimensions of HRQOL, based on the multidimensional model of health that is divided into two main components - the physical and the mental one. The assessment of each item is made by using the method of points scored with values ranging from 0 to 100 , where higher scores indicate better quality of life. The scores of the fields are derivatives from the scores of items of that field and the scores of physical and mental component derive from the fields associated with it.

\section{Statistical Analysis}

We used the computer program Statistical Package for the Social Sciences - SPSS ${ }^{\circledR}$ for Windows, version 20.0 to perform the statistical analysis. 


\section{Neurology \& Neurotherapy Open Access Journal}

To analyze the magnitude of relationship between SSN and HRQOL, the Spearman's correlation was used.

\section{Results}

The social and clinical characteristics of the sample are shown in Table1.

\begin{tabular}{|c|c|c|c|}
\hline Variables & $\mathbf{n}$ & $\%$ & M ( \pm Dp:Range.) \\
\hline Age (years) & 150 & & $41.7(10.5 ; 18-70)$ \\
\hline \multicolumn{4}{|c|}{ Sex } \\
\hline Female & 106 & 70.7 & \\
\hline Male & 44 & 29.3 & \\
\hline \multicolumn{4}{|c|}{ Marital status } \\
\hline Married & 99 & 66.0 & \\
\hline Single & 25 & 16.7 & \\
\hline Widow & 9 & 6.0 & \\
\hline Divorced or separated & 17 & 11.3 & \\
\hline \multicolumn{4}{|c|}{ School level } \\
\hline Inferior to primary education & 19 & 12.7 & \\
\hline Completed primary education & 58 & 38.7 & \\
\hline Completed secondary education & 48 & 32.0 & \\
\hline Completed higher education & 25 & 16.7 & \\
\hline \multicolumn{4}{|c|}{ Profession } \\
\hline Skilled workers & 71 & 47.3 & \\
\hline Unskilled workers & 79 & 52.7 & \\
\hline \multicolumn{4}{|c|}{ Clinical course of MS } \\
\hline Relapsing-remitting & 128 & 85.3 & \\
\hline Primary progressive & 6 & 4.0 & \\
\hline Secondary progressive & 16 & 10.7 & \\
\hline MS Duration (years) & 150 & & $9.1(6.4 ; 1-25)$ \\
\hline \multicolumn{4}{|c|}{ Disability } \\
\hline Low & 103 & 68.7 & \\
\hline Moderate & 29 & 19.3 & \\
\hline Severe & 18 & 12.0 & \\
\hline EDSS & 150 & & 2.5(2.4: 0-9) \\
\hline
\end{tabular}

Table 1: Sample description (social characteristics and disease parameters).

The mean age of patients is 41.7 years and the ratio women/men is 2.4.

Most patients are married (66.0\%), have a lower secondary education $(12.7 \% ; 38.7 \%)$ and unskilled occupations $(52.7 \%)$. The clinical parameters indicate that the form of relapsing and remitting MS is the most common (85.3\%), the mean duration of MS is 9.1 years $(6.4 ; 1-25)$ and the score of disability $(68.7 \%)$ is low.

The composition of SSN is shown in Table 2.

\begin{tabular}{|c|c|c|}
\hline \multicolumn{3}{|c|}{\begin{tabular}{c|c|r} 
Questions & N & $\%$ \\
How many relatives can you trust to talk about \\
almost anything?
\end{tabular}} \\
\hline \multicolumn{3}{|c|}{$\begin{array}{l}\text { How many relatives can you trust to talk about } \\
\text { almost anything? }\end{array}$} \\
\hline No relative & 15 & 10 \\
\hline One relative & 43 & 28.7 \\
\hline Two relatives & 37 & 24.7 \\
\hline Three relatives & 25 & 16.7 \\
\hline Four relatives & 12 & 8 \\
\hline Five relatives & 6 & 4 \\
\hline Six relatives & 7 & 4.7 \\
\hline Seven relatives & 4 & 2.7 \\
\hline Eight relatives & 1 & 0.7 \\
\hline
\end{tabular}




\section{Neurology \& Neurotherapy Open Access Journal}

\begin{tabular}{|c|c|c|}
\hline No friends & 38 & 25.3 \\
\hline One friends & 32 & 21.3 \\
\hline Two friends & 28 & 18.7 \\
\hline Three friends & 16 & 10.7 \\
\hline Four friends & 17 & 11.3 \\
\hline Five friends & 9 & 6 \\
\hline Six friends & 5 & 3.3 \\
\hline Seven friends & 2 & 1.3 \\
\hline Eight friends & 1 & 0.7 \\
\hline Ten friends & 2 & 1.3 \\
\hline \multicolumn{3}{|c|}{$\begin{array}{l}\text { Have you participated in sports in a group in the } \\
\text { last } 12 \text { months? }\end{array}$} \\
\hline No & 110 & 73.3 \\
\hline More than once per week & 13 & 8,7 \\
\hline Once a week & 2 & 1.3 \\
\hline Two or three times per week & 18 & 12 \\
\hline Few times a year & 7 & 4.7 \\
\hline Once a year & 0 & 0 \\
\hline \multicolumn{3}{|c|}{$\begin{array}{l}\text { Have you participated in meetings in the last } 12 \\
\text { months? }\end{array}$} \\
\hline No & 118 & 78.7 \\
\hline More than once per week & 12 & 8 \\
\hline Once a week & 5 & 3.3 \\
\hline Two or three times per week & 10 & 6.7 \\
\hline Few times a year & 0 & 0,0 \\
\hline Once a year & 5 & 3.3 \\
\hline \multicolumn{3}{|c|}{$\begin{array}{l}\text { Have you participated in voluntary work in the last } \\
\qquad 12 \text { months? }\end{array}$} \\
\hline No & 127 & 84.7 \\
\hline More than once per week & 14 & 9.3 \\
\hline Once a week & 2 & 1.3 \\
\hline Two or three times per week & 1 & 0.7 \\
\hline Few times a year & 5 & 3.3 \\
\hline Once a year & 1 & 0.7 \\
\hline
\end{tabular}

Table 2: Social Support Network.

This composition mostly consists of 1 to 3 relatives (28.7\%; $24.7 \%$; $16.7 \%$ ). However $10.0 \%$ of patients say they do not have family members with whom they can talk about almost everything.

Concerning_friends, $21.3 \%$ say they cannot trust them. But on the other hand most say they can count on one or more friends to talk about everything $(74.75 \%)$.

Most patients do not participate in Group sports $(73.3 \%)$, meetings $(78.7 \%)$ or in voluntary work (84.75\%).

The relationship between the SSN and HRQOL is shown in Table 3.

\begin{tabular}{|c|c|c|c|}
\hline \multicolumn{2}{|c|}{ Social Support Network } & \multirow{2}{*}{$\begin{array}{c}\begin{array}{c}\text { HRQOL } \\
\text { Physical } \\
\text { Health }\end{array} \\
.227^{* *}\end{array}$} & \multirow{2}{*}{$\begin{array}{r}\begin{array}{r}\text { HRQOL } \\
\text { Mental } \\
\text { Health }\end{array} \\
.302^{* *}\end{array}$} \\
\hline \multirow{3}{*}{$\begin{array}{l}\text { How many } \\
\text { relatives can } \\
\text { you trust to } \\
\text { talk about } \\
\text { almost } \\
\text { anything? }\end{array}$} & $\begin{array}{l}\text { Correlation } \\
\text { Coefficient }\end{array}$ & & \\
\hline & $\begin{array}{l}\text { Sig. (2- } \\
\text { tailed); p- } \\
\text { value }\end{array}$ & 0.005 & 0 \\
\hline & $\mathrm{N}$ & 150 & 150 \\
\hline \multirow{3}{*}{$\begin{array}{l}\text { How many } \\
\text { friends can } \\
\text { you trust to } \\
\text { talk about } \\
\text { almost } \\
\text { anything? }\end{array}$} & $\begin{array}{l}\text { Correlation } \\
\text { Coefficient }\end{array}$ & 0.159 & $.208^{*}$ \\
\hline & $\begin{array}{l}\text { Sig. (2- } \\
\text { tailed); p- } \\
\text { value }\end{array}$ & 0.051 & 0.011 \\
\hline & $\mathrm{N}$ & 150 & 150 \\
\hline \multirow{3}{*}{$\begin{array}{l}\text { Have you } \\
\text { participated in } \\
\text { sports in a } \\
\text { group in the } \\
\text { last } 12 \\
\text { months? }\end{array}$} & $\begin{array}{c}\text { Correlation } \\
\text { Coefficient }\end{array}$ & $.283^{* *}$ & $.221^{* *}$ \\
\hline & $\begin{array}{l}\text { Sig. (2- } \\
\text { tailed); p- } \\
\text { value }\end{array}$ & 0 & 0.007 \\
\hline & $\mathrm{N}$ & 150 & 150 \\
\hline \multirow{3}{*}{$\begin{array}{l}\text { Have you } \\
\text { participated in } \\
\text { meetings in } \\
\text { the last } 12 \\
\text { months? }\end{array}$} & $\begin{array}{l}\text { Correlation } \\
\text { Coefficient }\end{array}$ & $.280^{* *}$ & $.269^{* *}$ \\
\hline & $\begin{array}{l}\text { Sig. (2- } \\
\text { tailed); p- } \\
\text { value }\end{array}$ & 0.001 & 0.001 \\
\hline & $\mathrm{N}$ & 150 & 150 \\
\hline \multirow{3}{*}{$\begin{array}{c}\text { Have you } \\
\text { participated in } \\
\text { voluntary } \\
\text { work in the } \\
\text { last } 12 \\
\text { months? }\end{array}$} & $\begin{array}{c}\text { Correlation } \\
\text { Coefficient }\end{array}$ & $.245^{* *}$ & $.247^{* *}$ \\
\hline & $\begin{array}{l}\text { Sig. (2- } \\
\text { tailed); p- } \\
\text { value }\end{array}$ & 0.003 & 0.002 \\
\hline & $\mathrm{N}$ & 150 & 150 \\
\hline
\end{tabular}

* . Correlation is significant at the 0.05 level (2-tailed). **. Correlation is significant at the 0.01 level (2-tailed). Table3: The relationship between the SSN and HRQOL.

A statistically significant correlation between number of relatives, number of friends, participation in sports groups, participation in meetings, participation in volunteer work and mental dimension of HRQOL was found. The same correlation was observed for the physical dimension except for the question about the number of friends you can count onto talk about almost everything.

\section{Discussion}

The literature review showed that there are few studies about association between SSN and HRQOL of chronic patients $[17,19,22]$. 


\section{Neurology \& Neurotherapy Open Access Journal}

Moreover, there are no known studies about this field in MS patients. However, some studies show that participation in supporting groups for patients with MS is strongly linked to decreased anxiety and satisfaction with life [21] and supporting a person with MS has impact on the live so fin formal caregivers [28].

One explanation for the low frequency of this type of analysis may be linked to the fact that the concept of SSN is poorly defined due to the heterogeneity in the analysis of its dimensions held by investigators and sometimes is confused with other close concepts, such as social support $[17,2]$. This theoretical obstacle under takes the construction of the network measurement scales of social support systematizing how to measure all its dimensions. However, there is a consensus that SSN should be assessed in its composition, size, frequency of contact duration.

Concerning the composition, it may include family, neighbors and community organizations. The size refers to the number of people present in the network. The assessment of SSN may capture the frequency of contacts between the number of presented people present and the duration of such contacts where they settle.

The analyzed literature $[17,19,22]$ uses different scales to assess SSN: The Arizona Social Support Interview Survey [22], the Norbeck Social Support Questionnaire [19] and the Convoy of Social Support [17]. These studies are crosssectional type [17,19] or descriptive approach [22] with 224, 69 and 14 participants, respectively.

In this study, we used the Medical Outcomes Study Social Support Survey (MOS-SSS) because it is adapted to the Portuguese language and were used in the measurement of SSN.

Considering the lack of studies on the relationship between SSN and HRQOL of patients with MS, we compared the results of studies with other chronic patients.

The social characteristics of patients described in the literature show different results among them. However, we can observe that patients with spinal cord injury [22] have a mean age of 47.5 years, and 59.4 years for the cancer patients [17]. These ages are characteristics of a productive period of life. These mean ages are close to the age of patients of this study (Table 1), which is younger than patients of the samples analyzed.

The patients are mainly married (66.0\%) and females (70.7\%). Most have middle socioeconomic status which includes the education (38.7\%) and occupation (52.7\%).
No study presents an assessment of the physical disability of patients in order to compare with the MS patients (EDSS middle= 2.5; 2.4: 0-9).

Regarding the size of SSN (Table 2), the majority of MS patients reported that they have only one available person (relative 28.7\%; friends $21.3 \%$ ), two or three family members $(24.7 \% ; 16.7 \%)$ or friends $(18.7 \%$; $10.7 \%$ ) to help. This result is in line with the results of the reviewed studies, revealing that the SSN is Composed of family members and people that patients consider themselves friends, which indicates that the size associated with the type of bond has a positive effect in social support to patients $[3,17,30]$.

However, it is not known the relationship of other SSN dimensions (size, type of participants, contact frequency) with the HRQOL of patients. The analyzed studies concluded that there was a statistically significant relationship between the SSN and HRQOL, or SSN is associated with better RQOL patients studied ${ }^{23}$ which is a source of social support structure [22,30] and group member ship is strongly linked to life satisfaction ${ }^{21}$. These results are in accordance with the data from our study (Table 3) that discloses statistically significant positive correlations between SSN composition, social group membership, participation in voluntary work, conducting sports activities in group and HRQOL (physical health and mental health dimensions). The fact that someone has friends is correlated with the psychological dimension but not with the physical dimension of HRQOL.

Unlike other studies, we used MOSS because it also evaluates the levels of patient participation in sporting activities in groups, attending meetings and participating in volunteer work. In this study the frequency of participation is low, because the majority of patients reported they had not participated in activities in recent months, despite the levels of disability of the disease are minimal. It can be assumed that MS is not a disease that affects such participation, which seems to be the result of a SSN centered in family and friends and not in other social groups. However, despite the low participation in the mentioned social groups, it is correlated with HRQOL, which gives it a significant influence in this relationship.

\section{Conclusion}

Social support network composition, social group membership, conducting group sports and participation involuntary work, have an important role in HRQOL of patients with MS. 


\section{Neurology \& Neurotherapy Open Access Journal}

It is the SSN that provides the essential social support for the patient's adaptation to the daily living circumstances related with the disease.

The specialist working with MS has to look at the individualized patient and respective SSN as important elements of adaptation to illness and HRQOL, encouraging patients to participate in different social groups.

In practice, this study highlights the importance of multidisciplinary team in repairing the SSN that is often affected by the loss of social functions of MS patients.

\section{References}

1. Tortorella P, Lagana MM, Saresella M, Tavazzi E, Preti MG, et al. (2014) Determinants of disability in multiple sclerosis: an immunological and MRI study. BioMed research international 875768.

2. Tesar N, Baumhackl U, Kopp M, Gunther V (2003) Effects of psychological group therapy in patients with multiple sclerosis. Acta neurolScand 107(6): 394-399.

3. Costa DC, Sa MJ, Calheiros JM (2012) The effect of social support on the quality of life of patients with multiple sclerosis. Arquivos de neuro-psiquiatria 70(2): 108-113.

4. McCabew MP, De Judicibus M (2005) The effects of economic disadvantage on psychological well-being and quality of life among people with multiple sclerosis. Journal of health psychology 10(1): 163173.

5. Costa D, Sá MJ, Calheiros JM (2013) Social Characteristics and Quality of Life of Multiple Sclerosis Portuguese Patients. Neurol Ther 2(1): 4356.

6. Pack TG, Szirony GM, Kushner JD (2013) Bellaw JR Quality of life and employment in persons with multiple sclerosis. Work 49(2): 281-287.

7. Moore $\mathrm{P}$, Harding KE, Clarkson $\mathrm{H}$, Pickersgill TP, Wardle M, et al. (2013) Demographic and clinical factors associated with changes in employment in multiple sclerosis. Multiple sclerosis 19(12): 16471654.

8. Aljumah M, Alroughani R, Alsharoqi I, Bohlega SA, Dahdaleh M, et al. (2013) Future of management of multiple sclerosis in the middle East: a consensus view from specialists in ten countries. Multiple sclerosis international 952321.

9. Garnock-Jones KP (2014) Alemtuzumab: a review of its use in patients with relapsing multiple sclerosis. Drugs 74(4): 489-504.

10. Sa MJ (2014) Exercise therapy and multiple sclerosis: a systematic review. Journal of neurology 9(261): 1651-1661.

11. Ploughman M, Austin MW, Murdoch M, Kearney A, Godwin M, et al. (2012) The path to self-management: a qualitative study involving older people with multiple sclerosis. Physiotherapy Canada Physiother Can 64(1): 6-17.

12. Cosio D, Jin L, Siddique J, Mohr DC (2011) The effect of telephone-administered cognitive-behavioral therapy on quality of life among patients with multiple sclerosis. Ann of behav Med 41(2): 227-234.

13. Costa D, Sa MJ, Calheiros JM (2012) The effect of social support on the symptoms of depression experienced by Portuguese patients with multiple sclerosis. Arq Neuropsiquiatr 70(2): 108-113.

14. Kohlmann T, Wang C, Lipinski J, Hadker N, Caffrey E, et al. The impact of a patient support program for multiple sclerosis on patient satisfaction and subjective health status. The Journal of neuroscience nursing : Journal of the American Association of Neuroscience Nurses 45(3): E3-E14.

15. Finlayson ML, Cho CC (2011) A profile of support group use and need among middle-aged and older adults with multiple sclerosis. J gerontolo soc work 54(5): 475-493.

16. Schwartz C, Frohner R (2005) Contribution of demographic, medical, and social support variables in predicting the mental health dimension of quality of life among people with multiple sclerosis. Health soc work 30(3): 203-212.

17. Rodrigues JS, Ferreira NM (2012) Estrutura e funcionalidade da rede de apoio social do adulto com câncer. Acta Paul Enferm 25(5): 781-787.

18. Griep RH, Chor D, Faerstein E, Werneck GL, Lopes CS (2005) Construct validity of the Medical Outcomes Study's social support scale adapted to Portuguese in the Pro-Saude Study. Cadernos de saude publica 21(3): 703-714. 


\section{Neurology \& Neurotherapy Open Access Journal}

19. Forouzan AS, Shushtari JZ, Sajjadi H, Salimi Y, Dejman M (2013)Social Support Network among People Living with HIV/AIDS in Iran AIDS Research and Treatment 2013: 1-7.

20. Aboim S, Vasconcelos P, Support WK (2013) social networks and the family in Portugal: two decades of research. International Review of Sociology 23(1): 47-67.

21. Wakefield JR, Bickley S, Sani F (2013)The effects of identification with a support group on the mental health of people with multiple sclerosis. J psychosom res 74(5): 420-426.

22. Guilcher SJ, Casciro T, Lemieux-Charles L, Craven C, McColl MA, et al. (2012) Social networks and secondary health conditions: The critical secondcary team for individuals with spinal cord injury. The journal of spinal cord medicine 35(5): 330-342.

23. Soares A, Biasoli I, Scheliga A, Baptista RL, Brabo EP, et al. (2013) Association of social network and social support with health-related quality of life and fatigue in long-term survivors of Hodgkin lymphoma. Supportive care in cancer 21(8): 2153-2159.

24. Polman CH, Reingold SC, Banwell B, Clanet M, Cohen JA, et al. (2011) Diagnostic criteria for multiple sclerosis: 2010 revisions to the McDonald criteria. Annals of neurology 69(2): 292-302.
25. Kurtzke JF (1983) Rating neurologic impairment in multiple sclerosis: an expanded disability status scale (EDSS). Neurology 33(11): 444-1452.

26. Sherbourne C, Stewart A (1991) The MOS social support survey. Soc sci med 32(6): 705-714.

27. Ferreira PL (2000) Development of the Portuguese version of MOS SF-36. Part II -Validation tests. Acta medica portuguesa 13(3): 119-127.

28. McKeown LP, Porter-Armstrong AP, Baxter GD (2004) Caregivers of people with multiple sclerosis: experiences of support. Multiple sclerosis 10(2): 219230.

29. Hlebec V, Mrzel M, Kogovsek T (2009) Social Support Network and Received Suport at Stressful Events. Metodoloski zvezki 6(2): 155-171.

30. Forouzan AS, Jorjoran Shushtari Z, Sajjadi H, Salimi Y, Dejman M (2013) Social Support Network among People Living with HIV/AIDS in Iran. AIDS research and treatment 715381. 